\title{
Palustrine forested wetland vegetation communities change across an elevation gradient, Washington State, USA
}

\author{
Nate Hough-Snee ${ }^{\text {Corresp. } 1}$ \\ ${ }^{1}$ Four Peaks Environmental Science and Data Solutions, Wenatchee, Washington, United States \\ Corresponding Author: Nate Hough-Snee \\ Email address: nhoughsnee@fourpeaksenv.com
}

Background Forested wetlands support distinct vegetation and hydrology relative to upland forests and shrub-dominated or open water wetlands. Although forested wetland plant communities comprise unique habitats, these ecosystems' community structure is not well documented in the U.S. Pacific Northwest. Here I surveyed forested wetland vegetation to identify changes in community composition and structure across an elevation gradient that corresponds to flooding stress, asking: 1) how do forested wetland plant communities change across an elevation gradient that corresponds to flood frequency and duration? 2) At what relative elevations do different plant species occur within a wetland?

Methods I measured overstory tree basal area and structure and understory vascular plant composition in three zones: wetland buffers adjacent to the wetland, an upper wetland extent, and a lower wetland extent, surveying individual trees' root collar elevation relative to the wetland ordinary high-water mark. I estimated understory plant species abundance in sub-plots and surveyed these plots' height above the ordinary high-water mark (OHWM). I used non-metric multidimensional scaling ordination to identify patterns in vegetation communities relative to wetland elevation, and tested for compositional differences between the wetland buffer, upper wetland, and lower wetland zones using PERMANOVA. I calculated overstory and understory indicator species for each wetland zone using indicator species analysis.

Results Forest overstory composition changed across the elevation gradient, with broad-leaved trees occupying a distinct hydrologic niche in low-lying areas close to the OHWM. Conifer species occurred higher above the OHWM on drier microsites. Pseudotsuga menziesii (mean elevation $=0.881 \mathrm{~m}$ ) and Tsuga heterophylla (mean elevation $=1.737$ ) were overstory indicator species of the wetland buffer, while Fraxinus latifolia (mean elevation $=0.005$ ) was an overstory indicator for the upper and lower wetland. Understory vegetation differed between zones and lower zones' indicator species were generally hydrophytic species with adaptations that allow them to tolerate flooding stress at lower elevations. Average elevations above the OHWM are reported for 19 overstory trees and 61 understory plant species. By quantifying forested wetland plant species' affinities for different habitats across an inundation gradient, this study illustrates how rarely flooded, forested wetland buffer vegetation differs from frequently flooded, lower wetland vegetation. Because common management applications, like restoring forested wetlands and managing wetland responses to forest harvest, are both predicated upon understanding how vegetation relates to hydrology, this data on where different species might establish and persist along an inundation gradient, may be useful in planning for anticipated forested wetland responses to restoration and disturbance. 
1 Palustrine forested wetland vegetation communities change across an elevation gradient,

2 Washington State, USA.

3

4 Nate Hough-Snee ${ }^{1, *}$

5

$6 \quad{ }^{1}$ Four Peaks Environmental Science and Data Solutions, Wenatchee, WA, USA

7

8 Corresponding Author: Nate Hough-Snee

9 Address: Four Peaks Environmental Science and Data Solutions, Wenatchee, WA, USA

10 Email address: nhoughsnee@fourpeaksenv.com

11 *ORCID: 0000-0003-4581-0931 


\section{Abstract}

\section{Background}

14 Forested wetlands support distinct vegetation and hydrology relative to upland forests and shrub-

15 dominated or open water wetlands. Although forested wetland plant communities comprise

16 unique habitats, these ecosystems' community structure is not well documented in the U.S.

17 Pacific Northwest. Here I surveyed forested wetland vegetation to identify changes in

18 community composition and structure across an elevation gradient that corresponds to flooding

19 stress, asking: 1) how do forested wetland plant communities change across an elevation gradient

20 that corresponds to flood frequency and duration? 2) At what relative elevations do different

21 plant species occur within a wetland?

\section{Methods}

23 I measured overstory tree basal area and structure and understory vascular plant composition in

24 three zones: wetland buffers adjacent to the wetland, an upper wetland extent, and a lower

25 wetland extent, surveying individual trees' root collar elevation relative to the wetland ordinary

26 high-water mark. I estimated understory plant species abundance in sub-plots and surveyed these

27 plots' height above the ordinary high-water mark (OHWM). I used non-metric multidimensional

28 scaling ordination to identify patterns in vegetation communities relative to wetland elevation,

29 and tested for compositional differences between the wetland buffer, upper wetland, and lower

30 wetland zones using PERMANOVA. I calculated overstory and understory indicator species for

31 each wetland zone using Dufrene-Legendre indicator species analysis and multi-level pattern

32 analysis.

33 Results 
34 Forest overstory composition changed across the elevation gradient, with broad-leaved trees

35 occupying a distinct hydrologic niche in low-lying areas close to the OHWM. Conifer species

36 occurred higher above the OHWM on drier microsites. Pseudotsuga menziesii (mean elevation =

$370.881 \mathrm{~m})$ and Tsuga heterophylla (mean elevation $=1.737)$ were overstory indicator species of

38 the wetland buffer, while Fraxinus latifolia (mean elevation $=0.005$ ) was an overstory indicator

39 for the upper and lower wetland. Understory vegetation differed between zones and lower zones'

40 indicator species were generally hydrophytic species with adaptations that allow them to tolerate

41 flooding stress at lower elevations. Average elevations above the OHWM are reported for 19

42 overstory trees and 61 understory plant species. By quantifying forested wetland plant species'

43 affinities for different habitats across an inundation gradient, this study illustrates how rarely

44 flooded, forested wetland buffer vegetation differs from frequently flooded, lower wetland

45 vegetation. Because common management applications, like restoring forested wetlands and

46 managing wetland responses to forest harvest, are both predicated upon understanding how

47 vegetation relates to hydrology, this data on where different species might establish and persist

48 along an inundation gradient, may be useful in planning for anticipated forested wetland

49 responses to restoration and disturbance. 
51 Keywords: Forested wetlands, wetland vegetation, hydrologic gradients, palustrine wetlands,

52 Fraxinus latifolia, Carex obnupta, ecohydrology, community analysis, ordinary high-water mark 


\section{Introduction}

54 Forested wetlands, also known as "forested swamps" (Franklin \& Dyrness, 1988) and palustrine

55 forested wetlands (Cowardin et al., 1979), are biologically diverse ecosystems that support

56 unique plant communities. Within the U.S. Pacific Northwest these communities include upland

57 trees, shrubs, and herbs on elevated hummocks, and hydrophytic species that occur in low-lying

58 areas with high water tables and/or periodic to frequent inundation (Keogh, Keddy \& Fraser,

59 1999). While non-forested wetlands may include coniferous overstory trees at low abundance,

60 Pacific Northwest forested wetlands are unique in that mixed coniferous and deciduous tree

61 canopies often persist to old age (Painter, 2009) based on diverse microtopography available for

62 tree seedling establishment and hydrophytic tree species' relatively plastic adaptations to wetland

63 hydroperiods, anoxic soils, and overstory light environments (Harrington, 1987; Ewing, 1996;

64 Stolnack \& Naiman, 2010). Despite their unique composition, Pacific Northwest forested

65 wetlands' vegetation structure, including species size and location, are poorly understood relative

66 to upland forest ecosystems and non-forested wetlands (Painter, 2009; Adamus, 2014). Few

67 studies exist in the Pacific Northwest that quantify where forested wetland plant species, an

68 important component of wetland habitats, occur relative to hydrology or wetland elevation, a

69 proxy for wetland hydroperiod (Ewing, 1996; Hough-Snee et al., 2015b). Only Painter (2009)

70 has described forest structure and old tree size distributions in Pacific Northwest forested

71 wetlands.

73 Addressing this gap in understanding where wetland plants occur relative to elevation, and how

74 elevation corresponds to structure, may improve regional forested wetland conservation and

75 restoration actions as forested wetland vegetation is naturally distributed across hydrologic 
76 gradients (Brinson, 1993; Keogh, Keddy \& Fraser, 1999) and can be significantly altered by

77 hydrologic modification (Middleton \& Souter, 2016). For example, wetland restoration efforts

78 intended to mitigate forested wetland loss often plant tree species at appropriate elevations

79 relative to flooding so that plants successfully survive and grow and that restored wetlands'

80 vegetation composition eventually resembles the composition of functional forested wetlands

81 (Bledsoe \& Shear, 2000). Accordingly, studies of how forested wetland plants relate to even

82 coarse hydrologic indicators can improve the understanding of common forested wetland plant

83 species' hydrologic niches. This fundamental information can inform wetland restoration and

84 management that is predicated upon understanding what plant species can reasonably occur at

85 different elevations relative to soil inundation and surface water flooding.

87 Similarly, studies of where different plant species occur within forested wetlands can provide

88 hypotheses for how natural resource management activities, like timber harvest, that impact

89 wetland hydrology may impact forested wetland vegetation. Within Washington State forest

90 practices in and around forested wetlands ${ }^{1}$, including state-level buffer and harvest guidelines,

91 are based on the best available scientific literature, which is limited in the Pacific Northwest

92 (“Chapter 76.09 RCW: Forest Practices"; Beckett et al., 2016). Forested wetlands are managed

93 under Washington State Forest Practice Rules ("Chapter 76.09 RCW: Forest Practices";

94 Washington State Department of Natural Resources, 2005) to effectively result in "no net loss"

95 of ecosystem functions and services. This mandate means that wetlands, including forested

96 wetlands, should be managed around active forestry to maintain the processes that create diverse

97 vegetation structure and habitats, transport material and energy through watersheds, and that

\footnotetext{
${ }^{1}$ Washington State Forest Practice Rules define forested wetlands as "any wetland or portion thereof that has - or if the trees present were mature, would have - at least 30 percent canopy closure (Forest Practices Habitat Conservation Plan, 2005)..." from overstory trees.
} 
98 contribute to downstream water quality, flow regulation and flood attenuation. However,

99 watershed-scale logging alters forested wetland hydrology, often causing a rise in water tables,

100 and concurrent changes in vegetation composition (Timoney, Peterson \& Wein, 1997; Batzer,

101 Jackson \& Mosner, 2000) and tree growth (Ewing, 1996). Understanding at what elevations

102 different species occur across a flooding gradient may allow for the development of hypotheses

103 as to what species might be excluded from a given wetland by increased water levels associated

104 with forest harvest.

105

106 Here I investigated forested wetland vegetation composition and structure across a hydrologic

107 gradient asking two primary questions:

108 1. How do overstory forest composition and structure and understory forest composition

109 change across an elevation gradient from high to low above the ordinary high-water mark

$110 \quad$ within a palustrine forested wetland?

1112 2. At what elevations relative to the ordinary high-water mark are different plant species

112 found within forested wetlands?

113

114 Study Site

115 The study site was Ash Wetland, a 4.6-ha palustrine forested wetland (Cowardin et al., 1979)

116 located within 1,740-ha Pack Experimental Forest, a managed research forest in the Western

117 Cascades Lowlands and Valleys EcoRegion near Eatonville, Washington, USA (Figure 1). Ash

118 Wetland has an average elevation of 281-meters and is geographically isolated from surface flow

119 (Tiner, 2003). The water table rises with autumn and winter rain and falls throughout the

120 growing season into late summer, with water levels generally peaking in late winter to early 
121 spring. Plant and soil evapotranspiration often dry most of the wetland soil surface by late

122 summer in dry years. Mean daily temperature and total precipitation were $9.8^{\circ} \mathrm{C}$ and $118.36 \mathrm{~cm}$

123 from 1980 to 2010 ; during the year of the study (2009), mean daily temperature was $9.9^{\circ} \mathrm{C}$ and

124 total precipitation was $116 \mathrm{~cm}$ (PRISM Climate Group, Oregon State University,

125 http://prism.oregonstate.edu).

126

127 Methods

128 I used the Army Corps of Engineers' 1987 Wetland Delineation Manual (US Army Corps of

129 Engineers Environmental Laboratory, 1987) and Western Mountains, Valleys and Coasts

130 regional supplement (US Army Corps of Engineers, 2010) to determine the wetland-upland

131 boundary within Ash Wetland in September-November 2008, preliminarily surveying vegetation

132 and assessing hydric soil and hydrology indicators along the wetland boundary. From this initial

133 wetland delineation, I mapped the ordinary high-water mark (OHWM) and identified three $a$

134 priori zones across the wetland from which vegetation-elevation relationships were assessed:

135 wetland buffer, upper wetland, and lower wetland (Table 1). These zones were based on within

136 wetland elevation as it relates to the OHWM and used to stratify sampling as they mark breaks in

137 inundation. The wetland buffer (WB) zone was the area immediately upslope from the OHWM

138 and consisted almost entirely of non-hydric, upland soils. The upper wetland (UW) boundary

139 began at the OHWM and ran across an elevation gradient into the wetland. Upper wetland soil

140 pits were $>70 \%$ hydric soil types, either histic epipedon or histosols, and the lower wetland (LW)

141 was below the upper wetland and characterized by hydric soils with aquic moisture regimes

142 (Table 1). Sandy redoximorphic features, underlain by clay or rock restrictive layers, occurred in

143 portions of the upper wetland plots. 


\section{Vegetation Surveys}

146 Within each wetland zone I sampled vegetation within overstory plots containing nested

147 understory plots. Prior to sampling, I used GIS to overlay a 10-meter grid to the wetland and

148 randomly selected twelve plot locations adjacent to the wetland boundary at which sampling

149 would occur in all three zones. These points were field verified as being on the wetland edge 150 during the initial delineation, and $10 \mathrm{~m} \times 10 \mathrm{~m}$ overstory forest plots within the $\mathrm{WB}, \mathrm{UW}$, and

151 LW, were oriented parallel to wetland slope. This sampling scheme effectively resulted in a

152 stratified random sampling scheme with12 sampling locations serving as blocks and three plots,

153 one of each wetland zone (buffer, upper, lower) within each block (36 plots). One full set of

154 overstory plots could not be sampled due to dangerous wildlife resulting in 33 total overstory 155 plots (33 plots, $0.33 \mathrm{ha})$.

157 I identified all overstory trees $>2.5 \mathrm{~cm}$ in diameter and $>2 \mathrm{~m}$ in height within each overstory plot, 158 measured tree diameter at breast height $(\mathrm{DBH})$, and surveyed tree root collar elevation relative to

159 the OHWM elevation. Understory species cover was estimated within ten $1 \mathrm{~m} \times 1 \mathrm{~m}$ plots in each

160 forest plot. All understory shrubs $<2 \mathrm{~m}$ in height and $<2.5 \mathrm{~cm}$ in DBH were included in

161 understory vegetation cover and measured with herbs and forbs. Within the 33 plots sampled for 162 overstory trees, one full set of understory plots and one lower wetland plot had to be abandoned

163 due to dangerous wildlife (ground nesting wasps) resulting in 290 understory plots. All plots

164 were thought to be representative of Ash Wetland and so species rarefaction curves were not 165 created to evaluate at what sampling intensity unique species numbers diminished. 


\section{Elevation Surveys}

168 Base elevations of individual trees and understory plot centers were surveyed using a stadia rod

169 and level and related to temporary benchmarks at the OHWM at each sampling location. I

170 calculated height above the OHWM for each tree and plot by subtracting instrument height at

171 each benchmark from rod height using standard land surveying methods. Because survey

172 measurements were not linked to benchmarks with known elevations, all vegetation elevations

173 are relative to the OHWM elevation at that sample site.

175 Statistical Analyses

176 Individual tree species' mean elevation relative to the OHWM were compared using one-way

177 ANOVA and generalized linear hypothesis testing by Tukey's pairwise multiple comparisons in

178 the "mcp" function in the multcomp R package (Hothorn, Bretz \& Westfall, 2008). This

179 generalized linear hypothesis test approach was taken to test the hypothesis that elevation above

180 the OHWM differed based on species while controlling for potential type one errors as described

181 by Hothorn, Bretz \& Westfall (2008) and Bretz, Hothorn \& Westfall (2011). Species DBH and

182 elevation relative to the OHWM were plotted based on linear regression relationships to identify

183 trends in tree DBH and wetland elevation. Because this was an ad hoc exploratory analysis, not a

184 test of a mechanistic, causal relationship between tree size and elevation, formal statistical

185 hypothesis testing was not used. Six species, Spiraea douglasii, Taxus brevifolia, Abies grandis,

186 Ilex aquifolium, Oemleria cerasiformis, lacked sufficient replicates $(\mathrm{n}>2)$ to assess their

187 relationships between tree size and wetland elevation (Figure 2).

188 
189 Vegetation composition was compared across the elevation gradient using ordination methods,

190 hypothesis testing, and indicator species analysis. I converted DBH to basal area for each

191 overstory tree and calculated each species' relative basal density and relative frequency, from

192 which importance values were calculated for each overstory plot. Plot-level species importance

193 values (IV) were then used to calculate compositional dissimilarity between plots (Bray-Curtis

194 distance) from which overstory forest composition was compared using non-metric

195 multidimensional scaling (NMDS). NMDS ordination was also used to compare understory

196 vegetation by zone based on Bray-Curtis distance. Overstory species importance values and

197 understory abundance values were regressed against each ordination solution to identify

198 individual species relationships to community composition. Plot elevation was also regressed

199 against the understory NMDS ordination.

200

201 I quantified differences in wetland zones' overstory and understory vegetation composition using 202 PERMANOVA (Anderson, 2001; Oksanen et al., 2019; Table S1) and identified understory

203 indicator species for each of the wetland zones using indicator species analysis (ISA), including

204 multi-level pattern analysis for the understory and Dufrêne-Legendre ISA for the overstory

205 (Dufrêne \& Legendre, 1997; De Caceres, Legendre \& Moretti, 2010). For all overstory

206 community analyses the individual forest plots were the observational unit. For all understory

207 community analyses, individual vegetation quadrats within each overstory plot were the

208 observational unit and were stratified by wetland zone for both the PERMANOVA and indicator

209 species analysis permutation tests. All analyses were performed using R statistical software (R

210 Core Team, 2018). All statistical tests were performed with an alpha of $P<0.05$. 


\section{Results}

213 Plant species elevations above the ordinary high-water mark

214 I identified 19 overstory tree species and 61 understory plant species within the plots. Common

215 conifer species within the plots, Tsuga heterophylla, Pseudotsuga menziesii and the deciduous

216 shrub, Corylus cornuta occurred at the highest surveyed elevations, roughly one meter or more

217 above the OHWM (Figure 2; Figure 3). Thuja plicata, the most common conifer species,

218 occurred at a mean height of 0.53 meters above the OHWM. Of the common deciduous, broad-

219 leaved species, Fraxinus latifolia, Rhamnus purshiana, Alnus rubra, and Prunus emarginata

220 occurred near and slightly below the OHWM (Figure 2; Figure 3). Most shrubs occurred within

$22125-50 \mathrm{~cm}$ of the OHWM, except for Acer circinatum which occurred $0.64 \mathrm{~m}$ above the OHWM.

222 Cornus sericea, a hydrophytic shrub, occurred over 50 centimeters below the OHWM (Figure 2;

223 Figure 3).

224

225 For most tree species within the overstory, the relationship between elevation above the OHWM

226 and DBH was positive (Figure 2). That is, larger trees occurred higher above the most low-lying

227 areas within the wetland. Both $T$. heterophylla and C. sericea size were negatively correlated

228 with wetland elevation (Figure 2), meaning that larger individuals occurred in wetter, lower

229 locations within the wetland.

230

231 Overstory forest composition

232 I selected a three-dimensional NMDS ordination solution for overstory composition with an

233 observed stress of 0.066 (Non-metric fit $\mathrm{R}^{2}=0.996$; linear fit $\mathrm{R}^{2}=0.977$ ) and low probability of

234 the final solution's stress being artificially low as an artifact of the data structure $(P=0.040$; 
235 Monte Carlo randomization test). I also examined a scree plot of NMDS stress against NMDS

236 axes and found that NMDS stress decreased from two to three axes, but only marginally

237 decreased from three axes to four. This provided evidence for assessing community composition

238 with the three-dimensional NMDS solution.

240 Of the 19 overstory species sampled, F. latifolia $\left(\mathrm{R}^{2}=0.95\right)$, . plicata $\left(\mathrm{R}^{2}=0.92\right)$, P. menziesii

$241\left(\mathrm{R}^{2}=0.88\right)$, A rubra $\left(\mathrm{R}^{2}=0.77\right)$, A circinatum $\left(\mathrm{R}^{2}=0.61\right)$, C. sericea $\left(\mathrm{R}^{2}=0.38\right)$, and $P$.

242 emarginata $\left(\mathrm{R}^{2}=0.28\right)$ were all significantly correlated to the final ordination solution at the $P=$

2430.05 level (Figure 4). F. latifolia was positively correlated to the first and second NMDS axes

244 (Figure 4; Table S2), across both of which the gradient from upper wetland to lower wetland

245 showed compositional differences. P. menziesii and A. circinatum were strongly correlated to

246 negative scores across the second NMDS axis, where wetland buffer plots were most common

247 (Figure 4). Based on the elevations of individual species, positive to negative values across the

248 first and second NMDS axes could be interpreted as low and wet plots to high and dry plots.

250 Overstory forest composition differed between the wetland buffer, upper wetland, and lower

251 wetland plots (PERMANOVA R ${ }^{2}=0.25 ; P=0.0001$; Table S1). Pairwise comparisons indicated

252 that wetland buffer overstory composition significantly differed from that of the upper wetland

253 (PERMANOVA R ${ }^{2}=0.22 ; P=0.0001$ ) and lower wetland plot composition (PERMANOVA R ${ }^{2}$

$254=0.23 ; P=0.0008)$. The upper and lower wetland plots did not significantly differ in their

255 overstory composition (PERMANOVA $\mathrm{R}^{2}=0.02 ; P=0.82$ ). Because there was no difference

256 between the upper and lower wetland plots, I performed Dufrene-Legendre indicator species

257 analysis between the combined upper and lower wetland plots and the buffer plots. Indicator 
258 species analysis found that $P$. menziesii (indicator value $=93.9 ; P=0.005$ ) and $T$. heterophylla

259 (indicator value $=55.3 ; P=0.045$ ) were indicator species for the wetland buffer and $F$. latifolia

260 (indicator value $=81.6 ; P=0.03$ ) was the only significant indicator for the combined lower and

261 upper wetland zones (Table 2; Table S3).

262

263 Understory composition

264 I selected a three-dimensional NMDS ordination solution for understory composition with an

265 observed stress of 0.146 (non-metric fit $\mathrm{R}^{2}=0.979$; linear fit $\mathrm{R}^{2}=0.868$ ). Understory plot

266 distance above the OHWM was significantly positively associated with the first NMDS axis $\left(\mathrm{R}^{2}\right.$

$267=0.161 ; P=0.001)$. Both plot elevation above the OHWM and vegetation composition changed

268 across the first and second axes within the ordination. The second NMDS axis ran from high

269 (dry) to low (wet) from positive to negative values. The first NMDS axis ran from high (dry) to

270 low (wet) from negative to positive values. There were 24 plant species that were significantly

271 correlated with the final NMDS solution at the $P=0.05$ level (Figure 5; Table S2). Carex

272 obnupta, an obligate wetland species, was strongly associated with deeper, wetter habitats $\left(\mathrm{R}^{2}=\right.$

$2730.481)$ while in contrast, Gaultheria shallon $\left(\mathrm{R}^{2}=0.555\right)$ and Polystichum munitum $\left(\mathrm{R}^{2}=0.488\right)$

274 were more strongly associated with drier, higher habitats. Generally, plants with affinities or

275 tolerances for flooding occurred along the wet side of the ordination axes. Many plant species

276 were weakly but significantly associated with the final ordination solution (Table S2).

278 Understory composition differed among all of the wetland elevation zones (Table S1). Because

279 composition differed between all treatment zones, I used multi-level pattern indicator species

280 analysis (De Caceres, Legendre \& Moretti, 2010) to identify where species were indicators of 
281 multiple zones. The wetland buffer zone had four significant indicator species: P. munitum,

282 Mahonia nervosa, A. circinatum, and Gautheria ovatifolia (Table 3). Petasites frigidus was the

283 only significant understory upper wetland indicator species. There were six significant lower

284 wetland indicator species: Symphoricarpos albus, C. sericea, P. emarginata, Physocarpus

285 capitatus, Rosa nutkana, Amelanchier alnifolia. There were five significant indicator species of

286 both the upper and lower wetland: C. obnupta, Pteridium aquilinum, Spiraea douglasii,

287 Matricaria discoidea, Rubus spectabilis. Rubus ursinus was the only significant indicator species

288 for both the wetland buffer and lower wetland.

289

290 Discussion

291 Here I quantified how vegetation changes across an elevation gradient (question one) and the

292 elevations at which overstory and understory vascular plant species occurred within a palustrine

293 forested wetland (question two). Because wetland elevation corresponds to the frequency,

294 duration, and depth of flooding and soil saturation at a given location, pairing species and

295 elevation has numerous applications. Within a wetland, elevation from high to low dictates

296 where plant species can establish and survive across a flooding stress gradient that excludes

297 species without sufficient adaptations to flooding (e.g. aerenchyma, adventitious roots, etc.;

298 Keddy \& Ellis, 1985; Battaglia, Collins \& Sharitz, 2004). Accordingly, the elevation gradient

299 from high to low across which flooding stress increases is a measurable predictor of wetland

300 ecosystem composition, including soil chemistry (Yu \& Ehrenfeld, 2010), plant species

301 (Seabloom \& Van Der Valk, 2003), invertebrates (Gathman \& Burton, 2011), and microbes

302 (Ahn et al., 2009). The primary finding presented here, that forested wetland vegetation

303 composition shifts from generalist, upland species at high elevations to more specialist wetland 
304 species at low elevations, aligns with these well-documented studies of how wetland elevation

305 controls ecosystem processes.

306

307 Upland conifer species P. menziesii and T. heterophylla were the primary indicator species of the

308 wetland buffer and occurred one meter or more above the OHWM relative to deciduous species

309 like the upper and lower wetland indicator F. latifolia (Figure 6), which occurred roughly at the

310 OHWM. For the most abundant tree species, A. rubra, F. latifolia, T. plicata, and P. menziesii,

311 DBH was inversely correlated with depth above OHWM. This finding is consistent with studies

312 elsewhere that show more deeply and frequently flooded trees incur flood-induced physiological

313 stress that may impede growth or survival relative to trees at higher elevations or lower flooding

314 levels (Ewing, 1996; Walls, Wardrop \& Brooks, 2005). Other studies have shown that wetland

315 vegetation composition and structure changes across flood-stress gradients from low to high or

316 more frequently to less frequently inundated (Battaglia \& Sharitz, 2006; Gathman \& Burton,

317 2011; Berthelot et al., 2015).

318

319 The negative relationship between tree elevation and tree size for most species can be interpreted

320 one of two ways: flooded, (1) non-wetland trees are physiologically stressed and grow more

321 slowly in areas of frequent inundation and high flooding stress, or (2) environmental conditions

322 have changed as vegetation succession occurred and/or natural interannual hydrology varied,

323 allowing for the recent establishment of younger trees in certain microsites - hydrophytic species

324 in low, wet areas and upland species on fallen wood or stumps. While either or both of these

325 patterns are plausible, tree age was not measured alongside tree size, making it difficult to

326 decouple the causal mechanisms behind these observations. 
328 Several of the observed elevation differences between overstory species may be explained by

329 individual plant species' traits that allow them to persist in flooded conditions. For example, $F$.

330 latifolia, which occurred close to the OHWM and is also a facultative wetland species (FACW;

331 Lichvar et al. 2016), blooms late and drops seeds after peak floods have receded, a strategy that

332 avoids flooding (Lenssen, van de Steeg \& de Kroon, 2004). Previous research suggests that $A$.

333 rubra, a facultative wetland plant, is more sensitive to flooding than F. latifolia (Ewing, 1996),

334 but here I found no significant difference in the elevations at which overstory trees of both

335 species occurred.

336

337 Within the understory, A. rubra occurred at lower elevations than $F$. latifolia. This may be

338 attributable to $A$. rubra's dense seed rain and relatively fast growth rate, which allows seedlings

339 that establish to grow quickly enough to spread their roots to higher adjacent hummocks and

340 other landforms. C. obnupta, a rhizomatous and aerenchyma-dense obligate wetland plant, was

341 an indicator of both the upper and lower wetland, which is consistent with a greenhouse study

342 that showed the species to be physiologically resilient to different flooding regimes (Hough-

343 Snee, 2010; Hough-Snee et al., 2015b). The long-term survival and growth mechanisms for

344 many of the overstory and rhizomatous understory species observed within Ash Wetland may be

345 different than the short-term establishment and survival mechanisms examined in studies of

346 smaller seedlings and saplings (Ewing 1996).

\section{Applications to Wetland Management and Future Directions}

348 The data presented here illustrates where forest species occur relative to flooding (OHWM), and

349 this information can be used to place species into appropriate hydrologic context when 
350 anticipating wetland change from hydrology altering management activities, like forested

351 wetland and/or watershed timber harvest. While the observed relationships provide insight into

352 the natural history of Ash Wetland and similar palustrine forested wetlands, these relationships

353 also have implications for the management of other Pacific Northwest forested wetlands.

354 Watershed- and harvest unit-scale timber harvest, roads, and other land management that raises

355 water tables or increases the duration and magnitude of flooding will likely shift forest

356 composition toward hydrophytic stress tolerant species (Devito, Creed \& Fraser, 2005; Houlahan

357 et al., 2006).

358

359 In contrast, if forested wetlands are ditched or drained to facilitate forest harvest, then flood-

360 tolerant, hydrophytic species may be encroached upon by shade-tolerant upland species. These

361 hypotheses have not been tested within forested wetlands in Washington State, and any such

362 characterization of forested wetland dynamics over time in response to hydrologic modification

363 would immediately inform forested wetland management around industrial forests (Adamus,

364 2014; Beckett et al., 2016). Since forested wetland vegetation provides foundational habitat used

365 by birds (Cooke \& Zack, 2008) and mediates hydrological processes that contribute to

366 downstream aquatic habitats (Richardson, 2012), quantifying how forested wetland vegetation

367 may change in response to altered disturbance and hydrologic regimes is a research priority that

368 will directly inform biodiversity conservation in the Pacific Northwest and beyond.

370 This study provides context into where plant species occur along an elevation gradient that

371 reflects wetland hydrology within an isolated forested wetland. While the relationships between

372 species elevations and the OHWM are informative, the data presented here does not identify the 
373 specific mechanisms that allow some species to occur at a given location within the wetland and

374 while other species are precluded from occurring. For example, I used a coarse hydrologic

375 indicator (OHWM) to map the lateral hydrologic extent of a wetland, rather than measuring

376 hydrologic regimes over time. Forest managers often wish to know how harvest will change

377 hydrology at the stand to sub-basin scales and then how this change in hydrology will alter forest

378 composition over time. This study does not identify whether a given tree or species established

379 or matured during a wet or dry period or where the tree established relative to peak hydrology in

380 the year of establishment, but instead provides evidence of where species occur relative to

381 flooding stress.

382

383 Future regional investigations in forested wetland ecology should focus on how biological,

384 physiological, and hydrological attributes of these unique ecosystems intersect to shape forest

385 composition over multiple timeframes, including when and how forest species establish and

386 grow relative to frequent, low-magnitude flooding and infrequent, high-magnitude flooding

387 and/or drought. While interspecific patterns between species are explained here, intraspecific

388 trait diversity shapes species' capacity to tolerate stress, compete, and reproduce in flooded

389 environments (Hough-Snee et al., 2015b), with implications for how wetland plant communities

390 assemble (Hough-Snee et al., 2015a). Because species' genetics limit the range of traits that

391 allow species to establish and persist amid wetland hydrologic and biophysical stressors

392 (Lenssen et al., 2004), intraspecific variability in species' adaptations to flooding should also be

393 considered when comparing spatially disparate wetlands that hold the same species. 394 
395 Improving the body of knowledge around where different wetland species occur within wetlands

396 has applications to restoration planning. Restoration practitioners can assimilate species-

397 elevation relationships into wetland restoration plans by designing wetland planting gradients to

398 ensure that the most appropriate species are planted at a given location (hydrologic niche, or

399 elevation) within a wetland. Additionally, potential state and transition models can be created for

400 different forested wetland communities where vegetation may change over time as wetland

401 hydrology becomes wetter or drier from disturbance, restoration, or vegetation succession.

402

403 Conclusion

404 This study characterized the relationship between forested wetland plant species and relative

405 elevation above the ordinary high-water mark, a proxy for the hydrologic extent of a wetland. I

406 quantified the ranges of elevations across which species with adaptations to the wetland

407 environment were more likely to occur. Deciduous shrubs and trees occurred at lower elevations

408 within the wetland and had higher measured DBHs within flooded environments than upland

409 species that lacked adaptations to flooding. These results enumerate ecohydrological species-

410 elevation relationships within a Pacific Northwest palustrine forested wetland, relationships that

411 illustrate patterns of how different plant species are distributed relative to flooding stress.

412 Additionally, this study provides rare, regionally relevant observational data, a starting point

413 from which future hypotheses can be mechanistically tested to understand how different plant

414 species establish, grow, and persist within forested wetlands under different hydrologic regimes. 


\section{Acknowledgements:}

417 Derrick Cooper, Lexine Long, and Marco Negovschi were invaluable field helpers during this

418 project. Rodney Pond and Drs. Greg Ettl, Soo-Hyung Kim, and Lloyd Nackley were helpful

419 during experimental design. I am especially grateful to Dr. Kern Ewing (retired) for his

420 mentoring and advice during the M.S. degree from which this project originated. I greatly

421 appreciate his friendship and advice over the last decade. 


\section{References}

423 Adamus P. 2014. Wetland Research and Monitoring Strategy: Forest Practices and Wetlands.

$424 \quad$ Olympia, WA: Washington State Department of Natural Resources.

425 Ahn C, Gillevet PM, Sikaroodi M, Wolf KL. 2009. An assessment of soil bacterial community

426 structure and physicochemistry in two microtopographic locations of a palustrine forested

428 wetland. Wetlands Ecology and Management 17:397-407. DOI: 10.1007/s11273-008-

Anderson MJ. 2001. A new method for non-parametric multivariate analysis of variance. Austral Ecology 26:32-46.

Battaglia LL, Collins BS, Sharitz RR. 2004. Do published tolerance ratings and dispersal factors predict species distributions in bottomland hardwoods? Forest Ecology and Management 198:15-30. DOI: 10.1016/j.foreco.2004.02.066.

Battaglia LL, Sharitz RR. 2006. Responses of floodplain forest species to spatially condensed gradients: a test of the flood-shade tolerance tradeoff hypothesis. Oecologia 147:108118.

Batzer DP, Jackson CR, Mosner M. 2000. Influences of riparian logging on plants and invertebrates in small, depressional wetlands of Georgia, U.S.A. Hydrobiologia 441:123132. DOI: 10.1023/A:1017558523802.

Beckett L, Adamus P, Moore D, Sobota D, Haemmerle H. 2016. Forested Wetlands Effectiveness Project Best Available Science and Study Design Alternatives Document. Olympia, WA: Washington State Department of Natural Resources. Composition and Diversity of Tree Populations along a Hydrological Gradient in 
446 Bledsoe BP, Shear TH. 2000. Vegetation along a hydrologic and edaphic gradients in a North

447

448

449

450

451

452

453

454

455

456

457

458

459

460

461

462

463

464

465

466

467

468

Carolina coastal plain creek bottom and implications for restoration. Wetlands 20:126147.

Bretz F, Hothorn T, Westfall PH. 2011. Multiple comparisons using R. Boca Raton, FL: CRC Press.

Brinson M M. 1993. Changes in the functioning of wetlands along environmental gradients. Wetlands 13:65-74.

Cooke HA, Zack S. 2008. Influence of beaver dam density on riparian areas and riparian birds in shrubsteppe of Wyoming. Western North American Naturalist 68:365-373. DOI: 10.3398/1527-0904(2008)68[365:IOBDDO]2.0.CO;2.

Cowardin LM, Carter V, Golet FC, LaRoe ET. 1979. Classification of wetlands and deepwater habitats of the United States. Fish and Wildlife Service, US Department of the Interior Washington, DC, USA.

De Caceres M, Legendre P, Moretti M. 2010. Improving indicator species analysis by combining groups of sites. Oikos 119:1674-1684.

Devito KJ, Creed IF, Fraser CJD. 2005. Controls on runoff from a partially harvested aspenforested headwater catchment, Boreal Plain, Canada. Hydrological Processes 19:3-25. DOI: $10.1002 /$ hyp. 5776.

Dufrêne M, Legendre P. 1997. Species assemblages and indicator species: the need for a flexible asymmetrical approach. Ecological monographs 67:345-366.

Ewing K. 1996. Tolerance of four wetland plant species to flooding and sediment deposition. Environmental and Experimental Botany 36:131-146. DOI: 10.1016/00988472(96)01000-3. 
469 Forest Practices Habitat Conservation Plan. 2005. Olympia, WA: Washington State Department 470 of Natural Resources.

471 Franklin JF, Dyrness CT. 1988. Natural vegetation of Oregon and Washington. Corvallis, OR: $472 \quad$ Oregon State University Press.

473 Gathman JP, Burton TM. 2011. A Great Lakes Coastal Wetland Invertebrate Community 474 Gradient: Relative Influence of Flooding Regime and Vegetation Zonation. Wetlands 31:329-341. DOI: 10.1007/s13157-010-0140-9.

476

477

478

479

480

481

482

483

484

485

486

487

488

489

490

491 Biometrical Journal 50:346-363. DOI: 10.1002/bimj.200810425.

Hough-Snee NW. 2010. The effects of flooding depth, fertilization and initial seedling size on the growth and biomass allocation of two wetland sedges, Carex obnupta and Carex stipata. M.S. Thesis. Seattle, WA: University of Washington.

Hough-Snee N, Laub BG, Merritt DM, Long AL, Nackley LL, Roper BB, Wheaton JM. 2015 a. Multi-scale environmental filters and niche partitioning govern the distributions of riparian vegetation guilds. Ecosphere 6:art173. DOI: 10.1890/ES15-00064.1.

Hough-Snee N, Nackley LL, Kim S-H, Ewing K. 2015b. Does plant performance under stress explain divergent life history strategies? The effects of flooding and nutrient stress on two wetland sedges. Aquatic Botany 120:151-159. DOI: 10.1016/j.aquabot.2014.03.001.

Houlahan JE, Keddy PA, Makkay K, Findlay CS. 2006. The effects of adjacent land use on wetland species richness and community composition. Wetlands 26:79-96. DOI: 10.1672/0277-5212(2006)26[79:TEOALU]2.0.CO;2. 
492 Keddy PA, Ellis TH. 1985. Seedling recruitment of 11 wetland plant species along a water level 493 gradient: shared or distinct responses? Canadian Journal of Botany 63:1876-1879.

494 Keogh TM, Keddy PA, Fraser LH. 1999. Patterns of tree species richness in forested wetlands. Wetlands 19:639-647. DOI: 10.1007/BF03161701.

496

497

498

499

500

501

502

503

504

505

506

507

508

509

510

511

512

513

514

Lenssen JPM, van de Steeg HM, de Kroon H. 2004. Does Disturbance favour weak competitors? Mechanisms of changing plant abundance after flooding. Journal of Vegetation Science 15:305-314. DOI: 10.1111/j.1654-1103.2004.tb02229.x.

Lenssen JPM, Van Kleunen M, Fischer M, De Kroon H. 2004. Local adaptation of the clonal plant Ranunculus reptans to flooding along a small-scale gradient: Local adaptation to flooding. Journal of Ecology 92:696-706. DOI: 10.1111/j.0022-0477.2004.00895.x.

Middleton BA, Souter NJ. 2016. Functional integrity of freshwater forested wetlands, hydrologic alteration, and climate change. Ecosystem Health and Sustainability 2:e01200. DOI: $10.1002 /$ ehs 2.1200 .

Oksanen J, Blanchet FG, Friendly M, Kindt R, Legendre P, McGlinn D, Minchin PR, O’Hara RB, Simpson GL, Solymos P, Stevens MHH, Szoecs E, Wagner H. 2019. vegan: Community Ecology Package.

Painter L. 2009. Redefining Old-Growth in Forested Wetlands of Western Washington. Environmental Practice 11:68-83. DOI: 10.1017/S1466046609090164.

R Core Team. 2018. R: A Language and Environment for Statistical Computing. Vienna, Austria: R Foundation for Statistical Computing.

Richardson MC. 2012. Contributions of streamflow variability, concentration-discharge shifts and forested wetlands to terrestrial-aquatic solute export in Precambrian Shield headwater catchments. Ecohydrology 5:596-612. DOI: 10.1002/eco.244. 
515 Seabloom EW, Van Der Valk AG. 2003. The development of vegetative zonation patterns in

516 restored prairie pothole wetlands: Zonation patterns in restored wetlands. Journal of

517 Applied Ecology 40:92-100. DOI: 10.1046/j.1365-2664.2003.00764.x.

518 Stolnack SA, Naiman RJ. 2010. Patterns of conifer establishment and vigor on montane river

519 floodplains in Olympic National Park, Washington, USA. Canadian Journal of Forest

$520 \quad$ Research 40:410-422. DOI: 10.1139/X09-200.

521 Timoney KP, Peterson G, Wein R. 1997. Vegetation development of boreal riparian plant

522 communities after flooding, fire, and logging, Peace River, Canada. Forest Ecology and

$523 \quad$ Management 93:101-120.

524 Tiner RW. 2003. Geographically isolated wetlands of the United States. Wetlands 23:494-516.

525 DOI: 10.1672/0277-5212(2003)023[0494:GIWOTU]2.0.CO;2.

526 US Army Corps of Engineers. 2010. Regional Supplement to the Corps of Engineers Wetland

527 Delineation Manual: Western Mountains, Valleys, and Coast Region (Version 2.0).

$528 \quad$ Vicksburg, MS: U.S. Army Corps of Engineers.

529 US Army Corps of Engineers Environmental Laboratory. 1987. Corps of Engineers Wetlands

530 Delineation Manual. Vicksburg, MS: Prepared for U.S. Army Corps of Engineers.

531 Walls RL, Wardrop DH, Brooks RP. 2005. The impact of experimental sedimentation and

532 flooding on the growth and germination of floodplain trees. Plant Ecology 176:203-213.

533 DOI: $10.1007 / \mathrm{s} 11258-004-0089-y$.

534 Washington State Forest Practices Board. 1975. Washington State Forest Practices Act.

535 Yu S, Ehrenfeld JG. 2010. Relationships among plants, soils and microbial communities along a

536 hydrological gradient in the New Jersey Pinelands, USA. Annals of Botany 105:185-196.

537 DOI: $10.1093 / \mathrm{aob} / \mathrm{mcp} 183$. 
Figure 1

A map of Ash Wetland and the sampled vegetation plots within Pack Experimental Forest, Eatonville, WA, USA.

Black dots indicate locations where full overstory and understory sampling occurred. Green dots indicate plots where only overstory vegetation was sampled. The red dot indicates a plot intended for sampling that could not be sampled. 

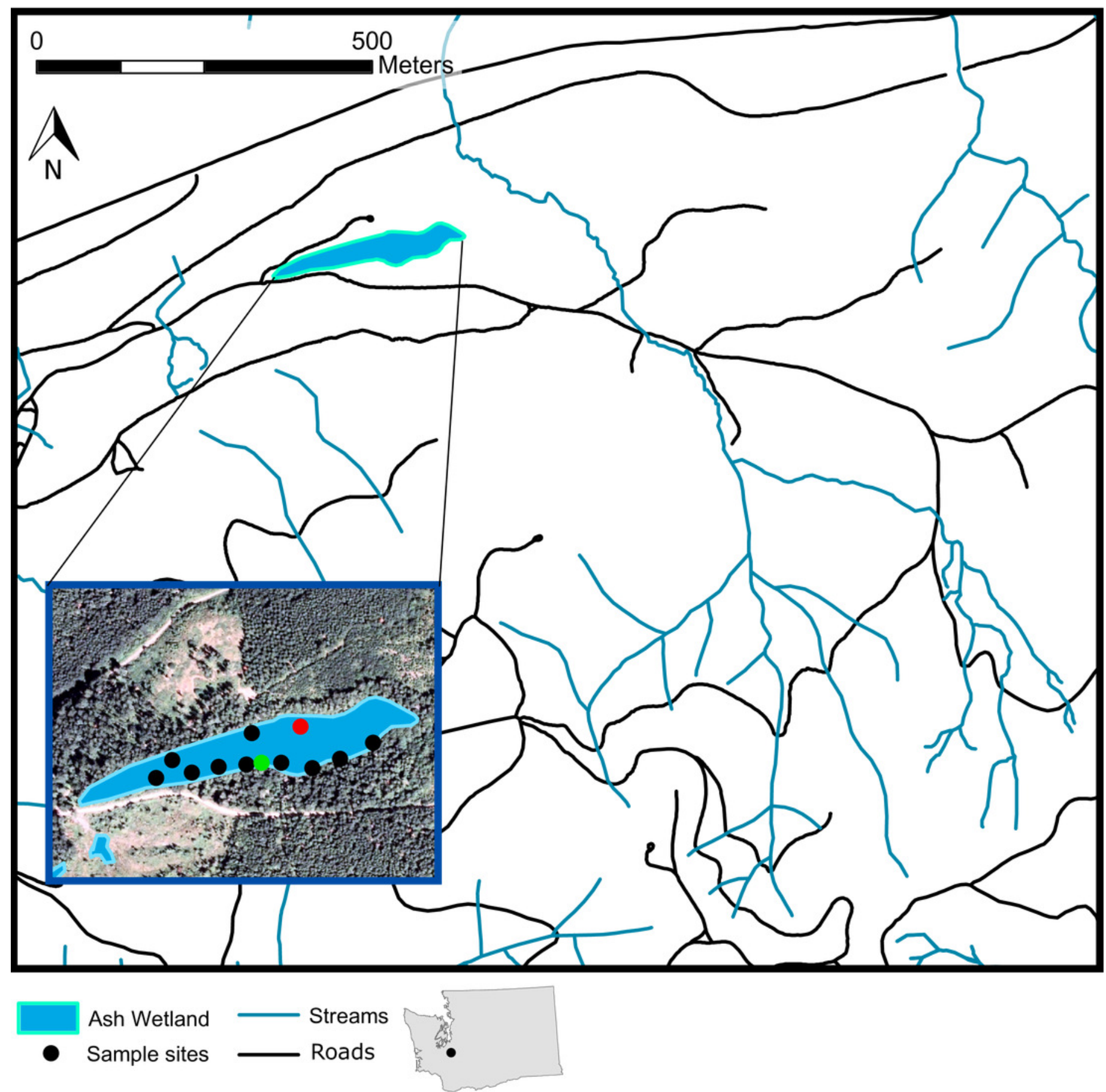


\section{Figure 2}

Individual tree elevation above the ordinary high-water mark (OHWM) plotted against measured tree diameter at breast height $(\mathrm{DBH})$ that was used to calculate estimated basal area.

Trees are plotted by species: A. Abies grandis, B. Acer circinatum, C. Acer macrophyllum, D. Alnus rubra, E. Corylus cornuta, F. Cornus sericea, G. Fraxinus latifolia, H. Holodiscus discolor, I. Ilex aquifolium, J. Oemleria cerasiformis, K. Physocarpus capitatus, L. Prunus emarginata, M. Pseudotsuga menziesii, N. Rhamnus purshiana, O. Rubus spectabilis, P. Spirea douglasii, Q. Taxus brevifolia, R. Thuja plicata, S. Tsuga heterophylla. Trend lines are the linear regression relationship between elevation above OHWM and tree $\mathrm{DBH}$, while point size reflects individual tree basal area $\left(\mathrm{m}^{2}\right)$. The shaded area is the $95 \%$ confidence interval for the regression relationship. Note that $\mathrm{C}, \mathrm{E}$, and $\mathrm{H}$ are low sample size observations and regression relationships have low confidence based on limited observations. 

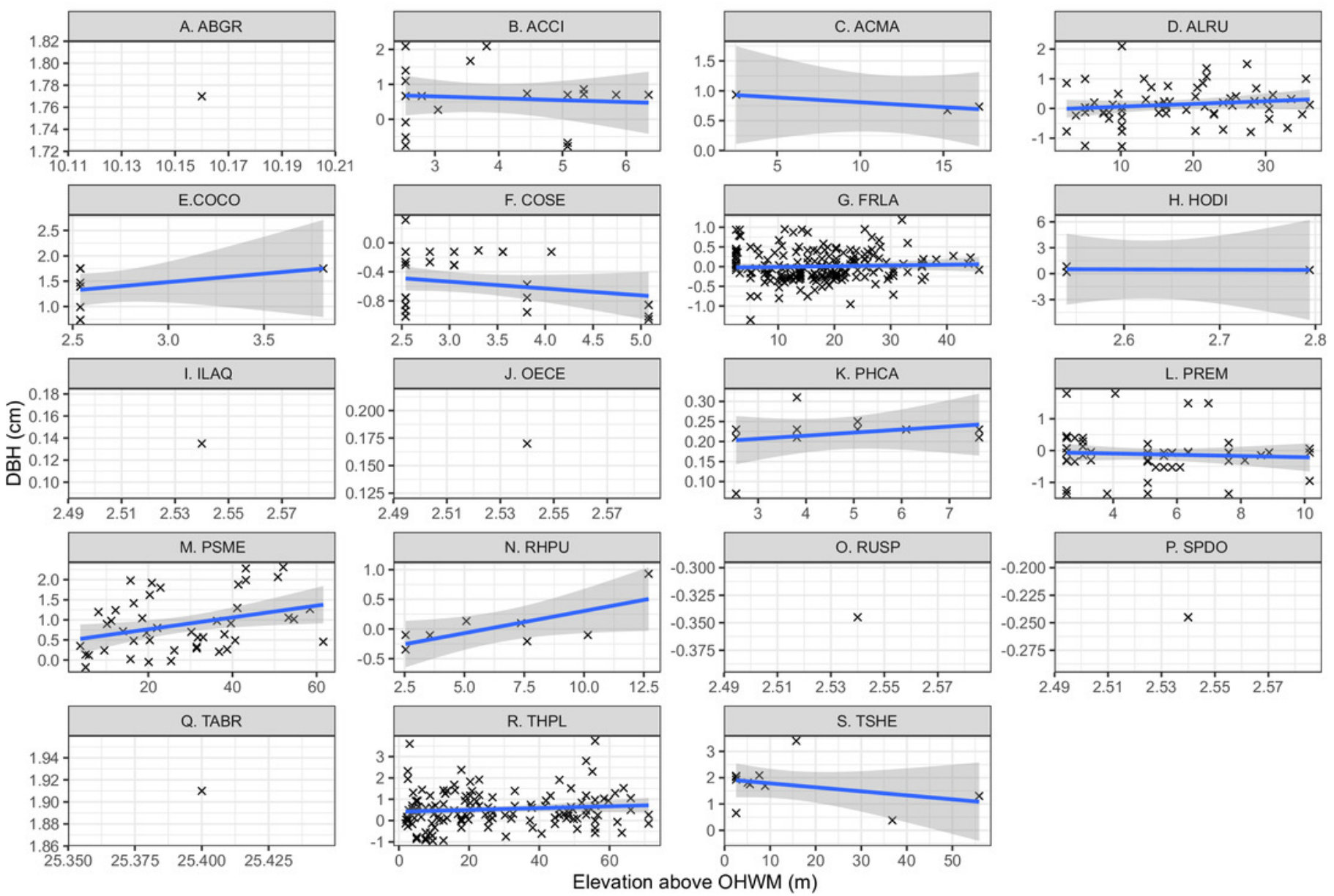

$\begin{array}{lllll}2.49 & 2.51 & 2.53 & 2.55 & 2.57\end{array}$ 
Figure 3

Box and whisker plot of individual trees elevations above the ordinary high-water mark (OHWM) by species.

Different letter values indicate statistically significant differences in the mean elevation between species detected by Tukey pairwise comparisons (One-way ANOVA F $=16.81, P=$ $\left.2 \mathrm{e}^{-16}\right)$. The bold line is the median and boxes are the 75th and 25th percentile of observations. Outlier values are any values over 1.5 times the interquartile range over the 75th percentile or any values under 1.5 times the interquartile range under the 25 th percentile.

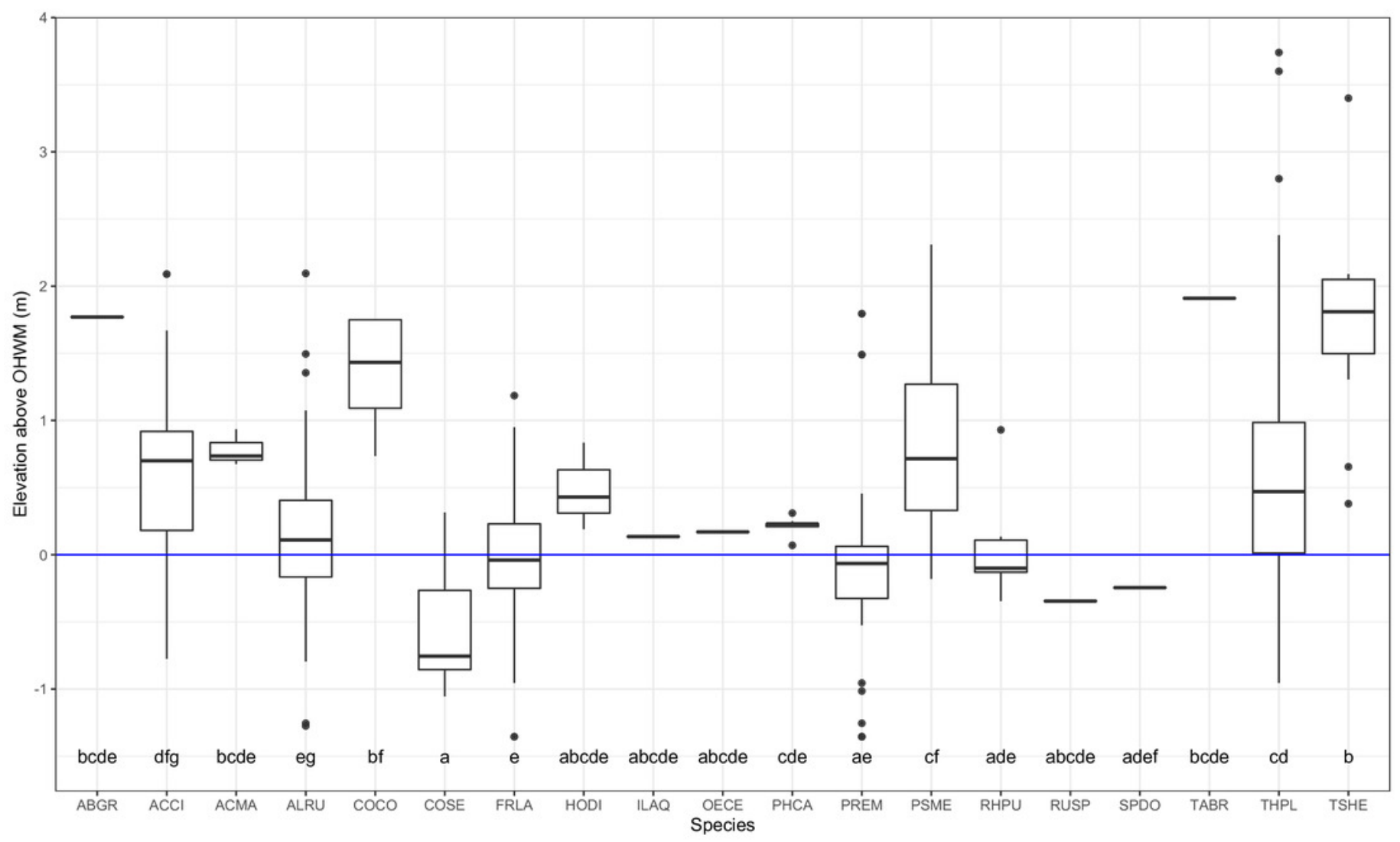




\section{Figure 4}

NMDS ordination of the overstory vegetation showed that the upper and lower wetland plots differed in composition from the wetland buffer, but not from one another and that vegetation differed across both axes reflective of hydrologic gradients

A. Overstory plots by treatment: buffer, upper, and lower wetland. B. Vectors indicate species that were significantly correlated to the final NMDS solution at the alpha of $P=0.05$. Species codes correspond to those in Table 3. 

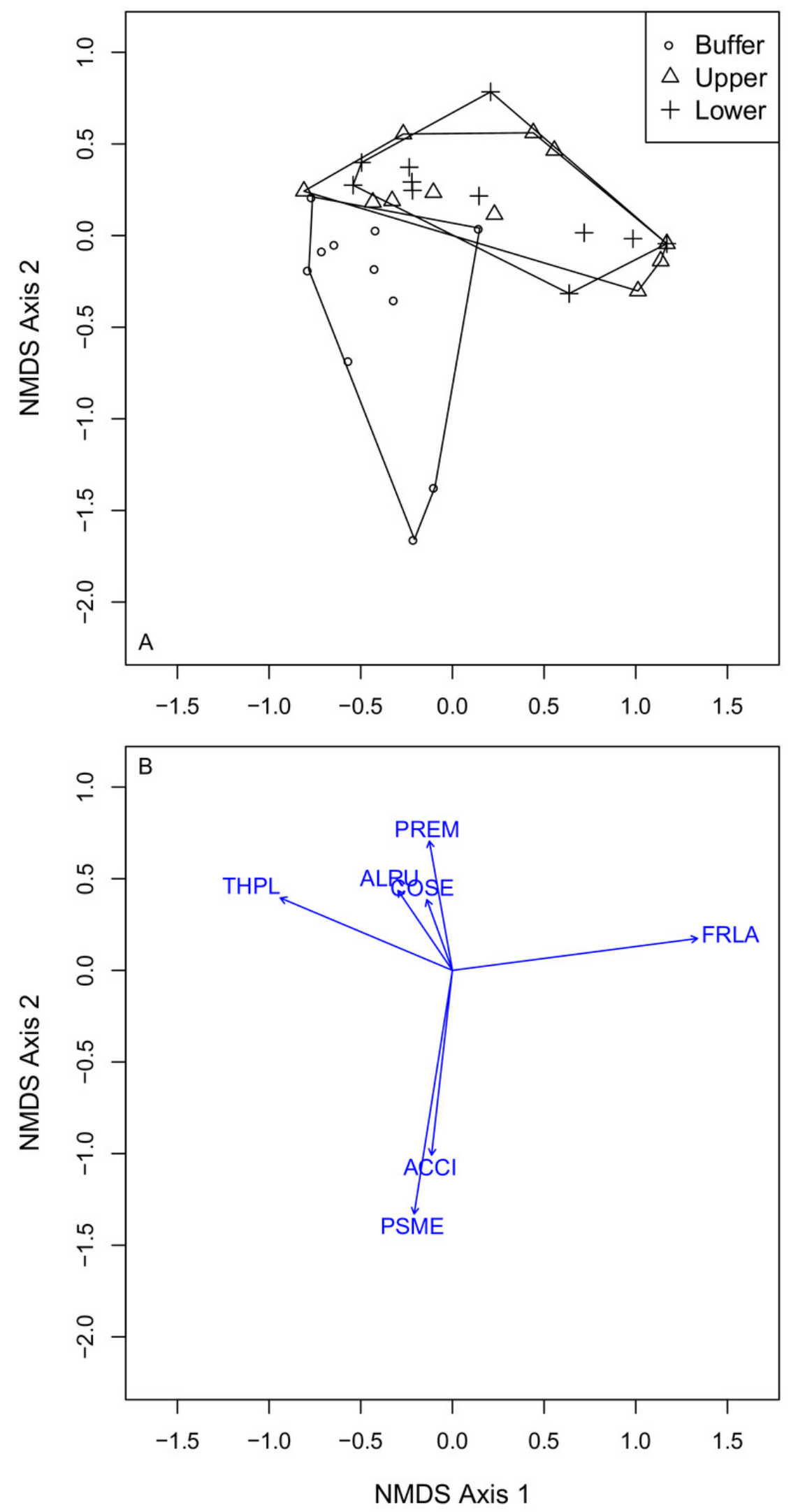

Peer] reviewing PDF | (2019:02:35220:2:0:NEW 28 Feb 2020) 
Figure 5

NMDS ordination of the understory plots showed that vegetation composition was distributed across a gradient from high elevations to low elevations.

A. Understory plots by treatment: buffer, upper, and lower wetland. B. Vectors indicate species that were significantly correlated to the final NMDS solution at the alpha of $P=0.05$. Species codes correspond to those in Table 3. 

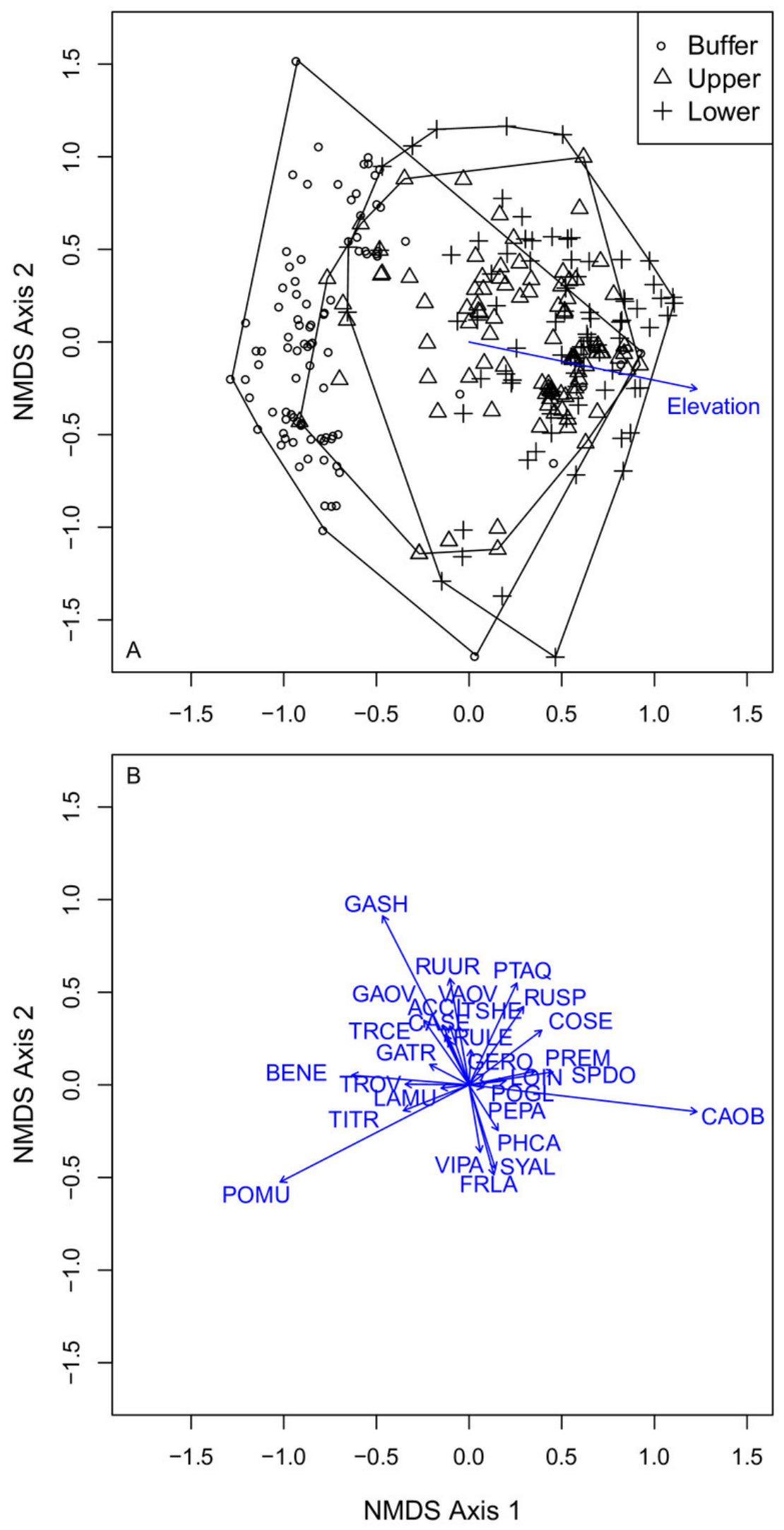


\section{Figure 6}

Figure 6. Examples of forest plots from high to low across the wetland buffer, upper wetland, and lower wetland groups.

Note overstory indicator species Pseudotsuga menziesii and Tsuga heterophylla alongside understory indicator Polystichum munitum in the wetland buffer row and upper and lower wetland overstory indicator species Fraxinus latifolia alongside understory upper and lower wetland indicator species Carex obnupta in the other rows.

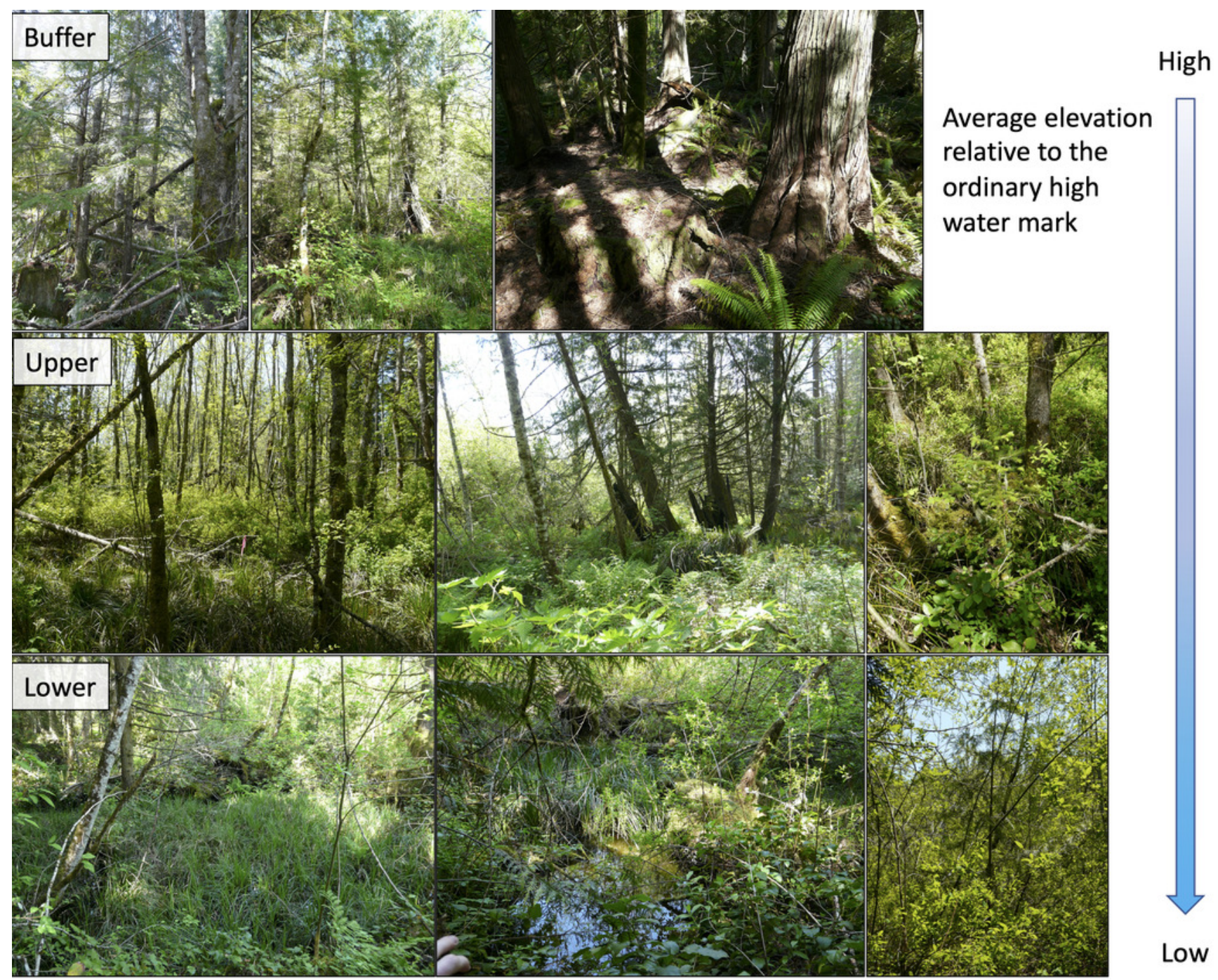




\section{Table $\mathbf{1}$ (on next page)}

Wetland zones related to the ordinary high-water mark (OHWM) across which vegetation sampling was stratified. 
1 Table 1: Wetland zones related to the ordinary high-water mark (OHWM) across which

2 vegetation sampling was stratified.

\begin{tabular}{|c|c|}
\hline Zone & Description \\
\hline Wetland Buffer (WB) & $\begin{array}{c}\text { Upland area slightly above the OHWM. Soils were not hydric, and } \\
\text { indicative of upland hydrology. Generally perched } 0.2 \mathrm{~m} \text { above the } \\
\text { OHWM except where higher elevation microtopography existed. }\end{array}$ \\
\hline Upper wetland (UW) & $\begin{array}{c}\text { The area that generally captured the OHWM and adjacent areas, } \\
\text { including wetland soils, but generally inundated by }<15 \mathrm{~cm} \text { of water } \\
\text { for a portion of the year }\end{array}$ \\
\hline Lower wetland (LW) & $\begin{array}{c}\text { Emergent, low wetland area below the OHWM, where standing } \\
\text { water persists during a large portion of the growing season, often at } \\
\text { depths }>15 \mathrm{~cm} .\end{array}$ \\
\hline
\end{tabular}




\section{Table 2 (on next page)}

Overstory tree indicator values derived from indicator species analysis.

Wetland indicator status is from the 2016 U.S. National Wetland Plant List (Lichvar et al., 2016): $\mathrm{OBL}=$ obligate wetland, $\mathrm{FACW}=$ facultative wetland, $\mathrm{FAC}=$ facultative, $\mathrm{UPL}=$ upland. For the full overstory indicator species list, see Table S3. 
1 Table 2: Overstory tree indicator values derived from indicator species analysis. Wetland

2 indicator status is from the 2016 U.S. National Wetland Plant List (Lichvar et al., 2016). For a

3 full overstory indicator species list, see Appendix 3.

\begin{tabular}{|l|l|l|l|l|l|l|}
\hline Species & Code & Zone & $\begin{array}{l}\text { Indicator } \\
\text { value }\end{array}$ & P & $\begin{array}{l}\text { Mean height } \\
\text { above } \\
\text { OHWM } \\
\text { (Meters) }\end{array}$ & $\begin{array}{l}\text { Wetland } \\
\text { indicator } \\
\text { status }\end{array}$ \\
\hline $\begin{array}{l}\text { Pseudotsuga } \\
\text { menziesii }\end{array}$ & PSME & Wetland buffer & 93.9 & 0.005 & 0.881 & FACU \\
\hline $\begin{array}{l}\text { Tsuga } \\
\text { heterophylla }\end{array}$ & TSHE & Wetland buffer & 55.3 & 0.025 & 1.737 & FACU \\
\hline $\begin{array}{l}\text { Fraxinus } \\
\text { latifolia }\end{array}$ & FRLA & $\begin{array}{l}\text { Upper - Lower } \\
\text { wetland }\end{array}$ & 81.6 & 0.035 & 0.005 & FACW \\
\hline
\end{tabular}

4 


\section{Table 3 (on next page)}

Understory community indicator values derived from indicator species analysis (multilevel pattern analysis).

WB $=$ Wetland buffer, UW $=$ Upper wetland, LW $=$ Lower wetland. Wetland indicator status is from the 2016 U.S. National Wetland Plant List (Lichvar et al., 2016): OBL = obligate wetland, FACW $=$ facultative wetland, FAC $=$ facultative, $U P L=$ upland. For the full understory indicator species list, see Table S3. 
1 Table 3: Understory community indicator values derived from indicator species analysis (multi-

2 level pattern analysis). WB $=$ Wetland buffer, $\mathrm{UW}=$ Upper wetland, $\mathrm{LW}=$ Lower wetland.

3 Wetland indicator status is from the 2016 U.S. National Wetland Plant List (Lichvar et al., 2016).

4 For a full understory indicator species list, see Appendix 3.

\begin{tabular}{|c|c|c|c|c|c|c|}
\hline Species & $\begin{array}{l}\text { Four- } \\
\text { letter } \\
\text { code }\end{array}$ & Zone & $\begin{array}{l}\text { Indicator } \\
\text { value }\end{array}$ & Probability & $\begin{array}{l}\text { Mean } \\
\text { height } \\
\text { above } \\
\text { OHWM } \\
\text { (Meters) }\end{array}$ & $\begin{array}{l}\text { Wetland } \\
\text { indicator } \\
\text { status }\end{array}$ \\
\hline $\begin{array}{l}\text { Polystichum } \\
\text { munitum }\end{array}$ & POMU & WB & 74.7 & 0.005 & 0.2978 & FACU \\
\hline Mahonia nervosa & BENE & WB & 52.9 & 0.005 & 0.6095 & FACU \\
\hline Acer circinatum & ACCI & WB & 25.6 & 0.015 & 0.6422 & FAC \\
\hline $\begin{array}{l}\text { Gaultheria } \\
\text { ovatifolia }\end{array}$ & GAOV & WB & 24.5 & 0.020 & 1.2367 & FAC \\
\hline $\begin{array}{l}\text { Petasites frigidus } \\
\text { ssp. palmatus }\end{array}$ & PEPA & UW & 20.0 & 0.04 & -0.6970 & FACW \\
\hline Carex obnupta & CAOB & $\begin{array}{l}\text { LW- } \\
\mathrm{UW}\end{array}$ & 86.9 & 0.005 & -0.4707 & OBL \\
\hline $\begin{array}{l}\text { Pteridium } \\
\text { aquilinum }\end{array}$ & PTAQ & $\begin{array}{l}\text { LW- } \\
\mathrm{UW}\end{array}$ & 45.9 & 0.005 & -0.1343 & FACU \\
\hline Spiraea douglasii & SPDO & $\begin{array}{l}\text { LW- } \\
\text { UW }\end{array}$ & 43.0 & 0.005 & -0.4968 & FACW \\
\hline $\begin{array}{l}\text { Matricaria } \\
\text { discoidea }\end{array}$ & MADI & $\begin{array}{l}\text { LW- } \\
\mathrm{UW}\end{array}$ & 38.1 & 0.045 & -0.2779 & FACU \\
\hline Rubus spectabilis & RUSP & $\begin{array}{l}\text { LW- } \\
\mathrm{UW}\end{array}$ & 36.3 & 0.005 & -0.3948 & FAC \\
\hline $\begin{array}{l}\text { Symphoricarpos } \\
\text { albus }\end{array}$ & SYAL & LW & 38.2 & 0.005 & -0.9969 & FACU \\
\hline Cornus sericea & COSE & LW & 37.6 & 0.005 & -0.2478 & FACW \\
\hline $\begin{array}{l}\text { Prunus } \\
\text { emarginata }\end{array}$ & PREM & LW & 33.5 & 0.020 & -0.1860 & FACU \\
\hline $\begin{array}{l}\text { Physocarpus } \\
\text { capitatus }\end{array}$ & PHCA & LW & 24.4 & 0.005 & -0.6970 & FACW \\
\hline Rosa nutkana & RONU & LW & 23.6 & 0.005 & -0.8680 & FAC \\
\hline $\begin{array}{l}\text { Amelanchier } \\
\text { alnifolia }\end{array}$ & AMAL & LW & 18.3 & 0.045 & -0.1733 & FACU \\
\hline Rubus ursinus & RUUR & $\begin{array}{l}\text { WB- } \\
\text { LW }\end{array}$ & 35.6 & 0.02 & -0.1626 & FACU \\
\hline
\end{tabular}

